\title{
APPEASED WITH DEATH: \\ OLD TESTAMENT INSIGHTS ON LIFE AND DEATH, FOR THE CHURCH IN AFRICA CONFRONTED BY HIV/AIDS
}

\begin{abstract}
Danie C van Zyl
Old and New Testament

Stellenbosch University

Abstract

Notions on life and death in the Old Testament are explored with reference to the $H I V$-Aids pandemic. These perspectives are firstly dealt with within the context of other Ancient Near Eastern notions and the social reality of Ancient Israel and are illustrated from a close and involved reading of Psalm 39. These are then discussed with reference to African views on life and death, suggesting ways in which the African church can contribute from the Old Testament in dealing with people living with HIV and Aids.
\end{abstract}

Key words: Life, Death, HIV-Aids, Psalm 39, Old Testament Worldview, African Worldview

In Africa death is one of the most important events of life. For the deceased it is the event of moving on to a new mode of living. For the living, the death of a member of the community creates the opportunity for sharing and caring, that is, for strengthening ubuntu. Both Christian and traditional rituals pertaining to burial and afterwards, serve the bereaved to come to grips with their loss and to see the diseased to a better life hereafter. This notwithstanding, death is largely a taboo topic; it is feared, and therefore little is done to prepare persons for death.

The reality of HIV and Aids brought new dimensions to individuals' and communities' experience of death and dying. Aids related deaths, particularly of younger people, are still on the increase in many communities in most parts of sub-Saharan Africa (Wachege 2002:187). Whole households and communities are reported to be wiped out. And no immediate change is to be expected: in certain remote areas of South Africa it is estimated that up to 60 percent of the population is HIV positive.

The reality of HIV and Aids confronts all sectors of society with unparalleled challenges. It challenges faith communities and religious leaders in particular to assist dying individuals and their families to cope with inescapable death and the many existential questions it brings about.

- Aids confronts us with untimely and in most cases youthful death. Total disruption of family and community life results, leaving millions of orphans behind.

- Sex, which is the very means of procreation and creating a continued community, is the key culprit in the spread of the HI-virus.

\footnotetext{
Research Fellow, Old Testament, Stellenbosch University.
} 
- In most cases those confronted with death because of Aids realize that it was caused by their own doing. Feelings of guilt and fear to disclose ones status because of prejudice add to emotional stress of patients.

- With HIV-Aids death is inescapable. No cure is as yet available. Medical science has not yet produced a remedy, while ritualistic cures and faith healers simply manage to create false hopes.

HIV and Aids challenges us to take a new look at the deeper meaning of life and death.

The New Testament has a particular view of life and death, and makes these central aspects of the Christian faith, since at the core of the Gospel message lies the birth, life, death and resurrection of Jesus. This New Testament perspective has the danger of silencing the voice of the Old Testament on life and death; or at least, we may fail to see the Old Testament roots of the New Testament proclamation.

Thus: What does the Old Testament say about life and death? And how does that relate to the life realities and world-view of African people who suffer so terribly from HIV and Aids. And: can that world-view perhaps contribute to Westerners' understanding where life has become more and more commercialised and focused on enjoyment, while death became a taboo issue, or is kept at a distance through the advance of medical sciences.

The way in which the Old Testament speaks of life and death should not be understood in a vacuum. What the Old Testament says comes to new life and perspective once it is read against the backdrop of Ancient Near Eastern thought about life and death. While in Ugaritic mythology Mōt, the deity Death, is the one who is responsible for the death of Ba'al, I could not find evidence indicating that he directly posed a threat to human life. Human life, according to Canaanite mythology, is more directly dependent on and ruled by Ba'al (Kraus 1979:205). In the natural cycle of Ba'al's annual death and rejuvenation, death and life are perceived as natural phenomena. Through ritualistic practices, communities and individuals could "tap" life-power from the deity and so ensure prosperity and ward off life threatening forces. But Ba'al could also become a furious god who would punish communities, and not so much individuals, through natural disasters in particular.

Life threatening forces on an individual level were more often attributed to evil forces or spirits. These could be manipulated and warded off through magical means. ${ }^{1}$ How magical practices were related to aspects of $\mathrm{Ba}$ 'al-worship and even ancestor veneration is not quite clear and probably varied over time. In Psalm 106:28, for example, sacrifices to the dead are associated with the worship of Ba'al-Peor. That ancestor worship, sometimes refer to as the "cult of the dead", was practiced by the Canaanites is clear (Eichrodt 1982:216-220). The widespread practice of consulting the dead through divination and magical means is, amongst others, attested to by Deuteronomy 18:9-14. However, one should guard against projecting perceptions from modern day cultures, for example African, into the way the Canaanites viewed the dead to ruled over the life and death of the living.

To what extent these Canaanite beliefs and practices associated with the dead were practiced in Ancient Israel is unclear. ${ }^{2}$ It is probable that those communities coming form a Canaanite background or living in close proximity to Canaanites might have shared in such practices. That it "was exactly the same" as in Canaanite communities, as stated by Rachel

See previous article in this series, dealing with Sickness and Healing.

For an overview of resent research, see Zulu 1998:17-22 and his own views on pages 78-86. 
Hallote (2001:64), and so without documentary or exegetical proof, is simply too sweeping a statement. ${ }^{3}$

It is clear that official Israelite religion was directly opposed to these Canaanite beliefs. The key factor in this is Israel's monotheistic faith, in which Yahweh is the only and true god who rules over life and death (Eichrodt 1982:216-220). Hallote presents an interesting additional argument. According to her Israel's rejection of ancestor practices had a strong political-ideological dimension. ${ }^{4}$

However it might have been, we need to keep in mind that what the Old Testament says about life and death was expressed by and addressed to people who lived within an environment where these above mentioned ideas were prevalent (Kraus 1979:207). Expressions, views and beliefs expressed in Biblical texts played with and against popular beliefs and real life practices of real people. The Psalms express heart-felt cries and faithwrestling, expressed in poetic speech. By nature metaphors are open ended, moving by will, particularly by will of the listener or reader, between real life experiences and symbolic meaning.

We now move to draw a few essential contours of the way in which the Old Testament speaks about life and death. The Old Testament believers accepted death as a natural phenomenon. Biblical anthropology attests to this. The human being is bãs ãr, created from the dust (עפר מן־האדמה) of this earth, and in death s/he returns to dust. The fact that God breathed His "breath of life" (נשמת חיים) into him, does not make the human godly or immortal, it makes him a "living soul" (נפש חיה, Gen 2:7). This view expresses that life is a gift from Israel's Creator God. Although the Old Testament views the human being as both bãśã and rüah, it does not view the human being in a dualistic manner. The concept nefeš refers to the human being as a whole, it expresses an essentially holistic view of the human being (Eichrodt 1982:131-150; Kraus 1979:180-184).

For the major part of the Old Testament there is no life without existence in the body. For that reason what the Old Testament says about life has to do with existence in this earthly reality. The way in which the Old Testament speaks about life and death demonstrates its essential "diesseitige" perspective on reality:

In line with its Umwelt, the Old Testament acknowledges existence beyond death, in

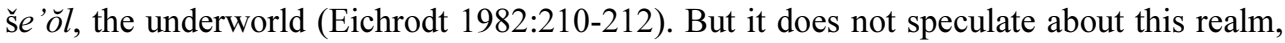
and does not call that "life". It is largely negative about what lies beyond the grave, probably so in opposition to its neighbours' beliefs. In še'ŏl the essential aspects of what the Old Testament associates with life, namely communion with the covenant community, and thus with the cultic community, and thereby with the living God Yahweh, are missing. There the essence of life, praise of Yahweh, is not possible (Von Rad 1975:368-370). It acknowledges that contact with those in the underworld is possible, as the case of Saul consulting Samuel (1 Sam. 28) shows. But this is all along condemned as part of Canaanite faith. That the dead can communicate with the living or influence them of their own will, as is commonly believed in Africa, for example, is nowhere suggested in the Hebrew Bible.

\footnotetext{
She simply quotes verses, accepting that every reference to heights, for example, refers to the "cult of the dead", and that it was practiced by Israelites and Canaanites without distinction (Hallote 2001:64). All along she presents what she says as facts, though in one of the very few footnotes which she gives, she states that what she says is substantiated by the hypothesis of Bloch-Smith and others (her note 4 page 216).

4 According to her Israel not only venerated family ancestors, but also clan and tribal ancestors. These latter cults served tribal unity and identity, but posed a threat to national unity . Therefore, with the rise of the monarchy, the cult of the dead was banned for ideological reasons (Hallote 2001:55f).
} 
The focus of the Old Testament is on life, this earthly life. The essence of life is shalom, well-being, in a holistic sense. There is no separation of physical, emotional, social and religious dimensions of life; these are all intricately bound together, as we have seen in the previous discussion on sickness and healing. Essential to well-being is to be meaningfully integrated within ones community. Being a stranger is in a sense to be deprived of life (Psalm 39:13). To play a functional role in one's family and local community means to live a good life. In the Old Testament, being part of the physical (blood-) and national community, it is the covenant community, is directly linked with being a member of the cultic community. Thus ones relationship with Yahweh, the source of life, is tied up with all aspects of ones life (see footnote 1).

Life is a gift from God. As Creator and as God of history, for Israel Yahweh is the source of all life (Kraus 1979:205,206). For well-being in whatever aspect of life, be it in family or society, in daily enterprise or in national matters (for example in war), the individual and community depend on God. Faithfulness to the covenant commands ensures the life-giving favour of Yahweh, not for some ritualistic or mystical reasons, but particularly because these commands are geared at promoting good and just relationships with the earth, the community and with Israel's covenant God. This stands over against the magical practices of Israel's neighbours which were aimed at warding off life-threatening evil spirits or powers and against ritualistic cults through which the life-giving power of the deities could be taped.

In Israel the cult was the central venue and occasion for celebrating life. Here Yahweh was praised for His blessings in daily and national life, for protection and for salvation. Where praises die down for whatever reason, life fades, because, for the Old Testament believer, praise of Yahweh is life (Von Rad 1975:368-370). The Old Testament thus has essentially a very positive, even celebratory, view of life. It proclaims that Yahweh has control over the life of individuals and of the community, He directs it. Therefore prayer, both by the individual and community, plays an important role in the cult. Through prayer believers confess their dependence on Yahweh and bring their fears and needs to Him. Here they implore His protection, help en blessings, in one word: life. In the cult He reveals His will for His people, through the proclamation of this law by priests and revelations through prophets. Therefore mediums who consult spirits who "peep and mutter"(Is. 8:19) are not only forbidden, they are not needed.

Whatever threatens life in this holistic sense was seen as agents of death. The Psalms often express that death was a feared force (55:5). In a sense death was regarded as a lifeinvading force. Death was therefore more than the physical moment of separation of body and spirit (Brueggemann 2002:48). Whatever disrupted communion and the relations in which one lived, diminished life and were early stages of death. Thus even being far from home and from the cultic community was dangerous; there life lost its meaning (Kraus 1979:207-208).

Sickness, natural disasters and national crisis (war), but also social injustice, and for that matter anything that has economic implications for the individual or community, disturbs shalom and diminishes the quality of life. All these four life threatening aspects were causes of untimely death. Therefore unnatural death was feared and regarded as a curse, the opposite of shalom. Untimely death disrupted all relationships and had dramatic implications for the family in particular. In the case of the death of a male, it not only left the family without a bread-winner. It also had negative economic and social implications by leaving the spouse as widow and children as orphans. Death of a person who do not have children yet puts the family line and the covenant community in jeopardy. 
Since Yahweh is the giver and controller of all life, unnatural death is mostly viewed as withdrawal of His favour, as judgement. Because He is not a furious or ill-tempered God, the natural reaction was to ask how the individual or community has offended Him. In the Psalms Yahweh is often addresses in prayer in the face of death; He is even accused as the one responsible for death, particularly for imminent or untimely death, as is the case in Psalm 39.

Dying in old age, having experienced a good life in community and cult, and leaving behind off-springs who can carry the family line, was considered a blessing. But dying young cuts one off from all these blessings and the looming "gates of še'ol" pose utter anguish. This is vividly illustrated in the emotional prayer in Psalm 39. Yahweh is confessed to have power to save from looming death (Brueggemann 2002:49). še 'ŏl does not fall outside His rule, and even in death the believers trust not to be separated from His favour: כי־טוב חסדך מחיים (Ps. 63:4). Thus the Old Testament believer knows that prayer is the only means he/she has of clinging to life, exactly through clinging to Yahweh! But this prayer is no formalistic or ritualistic duty, it is a heart-felt emotional outburst in which Yahweh can be accused and beseeched, where confession of guilt and utter despair stand alongside one another, without any logic, or shame. Sometimes there is a dramatic change in the mood of the prayer towards praise, or at least acceptance. But true to life, that does not always, and above all automatically, happens when someone in this condition is praying, as Psalm 39 attests.

Psalm 39 offers an exceptional example of how believers of the first covenant experienced the threat of death and how they handled this threat in faith. It illustrates how the essential and existential faith relationship with Yahweh, which was singled out in the previous paragraph as the key to understanding life and coping with death in the Old Testament, in fact operated. Psalm 39 is prayer-song (Gebedslied) by a person confronted by imminent death, and who is wrestling with the meaning of life. When one reads it with the eyes and a heart of someone with Aids ${ }^{5}$ who faces his/her own death, this prayer attains new dimensions. Reading such a Psalm from a specific crisis situation, like Aids, opens perspectives of faith and brings inner change which escapes the uninvolved reader. Brueggemann writes meaningfully in this regard about "a presupposition about language that is necessary to enter into the Psalms". He continues:

In our (Western) culture, we imbibe a positivistic understanding of language. That is, we believe that the function of language is to report and describe what already exists... But it is one-dimensional language that must necessarily be without passion and eloquence and indeed without boldness... By contrast, in the Psalms the use of language does not describe what is. It evokes to being what is not until it has been spoken. This type of language resists discipline, shuns precision, delights in ambiguity, is profoundly creative... It races on ahead to form something new that was never before... The creative speech of the poet can evoke new forms of human life... Such speech, which is the proper idiom for prayer, is the language of surprise. It means that in such speech both the speaker and God may be surprised by what is freshly offered (1986:27-29).

In the first verses (39:2-4) Psalm 39 gives a glimpse of the emotional struggle and pain of a person confronted by imminent death who tries to keep his/her feelings for him/herself. Like many an Aids sufferer he feared to approach God in prayer or to share his pain with

It is noteworthy that the word for "plague" (naga' 39:11) is used 33 times in Leviticus 13 alone in reference to leprosy, the most feared and incurable disease of old. 
others. Expressions like a "warm heart" and "groaning"" bear witness to the intensity of emotions and pain.

Then an appeal is launched at Yahweh (39:5-7). Verse 5 is a plea that Yahweh may let him know how close to his death is. This may be read either to express a longing to die soon or to be saved, but at least he confesses that his "days" are in the hands of covenant God. The Psalmist laments that his life has become meaningless, a waste, which he terms as "nothing" (צלם) and "vanity".

Verse 8 is probably the climax of this Psalm ${ }^{9}$. If the text variation of GS is accepted (Kraus 1978:451-452), this verse forms a perfect parallelism. Even if not, both parts express the same strong idea of hope through the use of semantic closely related terms (Westermann 1979:624-625). Significant in terms of what was said above about Yahweh as the keystone in the Old Testament perception of what life means, this verse explicitly makes him the object and contents of hope. ${ }^{10} \mathrm{Here} \mathrm{He}$ is, moreover, intimately called Adōnai.

The prayer that follows (39:9-12) confesses that what the Psalmist experiences are the correcting measures of Yahweh on what he confesses as his wrongful conduct. Many people suffering of Aids experience feelings of guilt and shame, even when they have contracted the HI-virus without any "wrongdoing" on their part. Stigmatising ${ }^{11}$ make people afraid even to speak their pains in prayer (see 39:10).

The Psalm ends in a very strong appeal to Yahweh to hear ${ }^{12}$ his prayer $^{13}$ (39:13). The appeal is motivated in an exceptional manner by the Psalmist describing himself as a foreigner ${ }^{14}$. Verse 14 seems to contradict the appeal in verse 13, since it asks to be left alone, it is that Yahweh should withdraw His hand of punishment (:11) in order that the afflicted person may experience a little joy (Job 10:20) before passing ${ }^{15}$ into nothingness. ${ }^{16}$

As was indicated earlier, the bulk of the Old Testament speaks of life and death in diesseitige terms. It is dubious to try to reconstruct the religions-geschichtlige development of the perceptions of ancient Israel with regard to death in particular. It is impossible to determain when to date and under what influences notions of a reality beyond this life, where the relationship with Yahweh can be continued, entered the Old Testament. It is, however, widely accepted that it was through the intensive contact with Babylonian cos-

\footnotetext{
חס־לב expresses, amongst other, anger and vengeance, Deutr 19:6.

הגיג, an animal sound, re. also Ezek. 2:10.

הבל הבר, used 3 times (verses 6, 7, 12). Though a wisdom motive in the tradition of Ecclesiastes may be reflected in verse 7, the Sitz im Leben of this Psalm is totally different.

9 This Psalm reflects a pyramid structure: In mood, themes and the use of terminology, though not fully identical, verses 2-7 are complemented by verses 9-14. Note for example the use of divine names.

10 Note the similarities with the key verse in Psalm 38:16, and the use of divine names there.

11 Verse $9 b$ contains an element of irony in the fact that the reproach comes from a fool (nābā $l)$.

12 To hear (שמע, Schult 1979:978-980) is strengthened and qualified positively by to give ear (אif.) and negatively by be not deaf (חשרש); see Ps. 28:1.

13 Prayer is qualified with strong emotional terms: cry (שועה, Albertz 1979:569-570) and tears.

14 גור, Martin-Achard 1978:410-412; also recall what was said about the holistic experience of death as separation from community and from Yahweh. The additional clause a pilgrim like all my fathers may, however, sound a positive note.

15 הלך, fading away like a snail (Ps. 58:8-9).

16 אין If one compares this to what Schwertner (1978:128-129) says about this expression concerning other gods who "are not", this does not mean that the Psalmist says that in death he no longer exists, but that that he has become a person of no meaning. This is a very pertinent way to express how Old Testament believers thought about life beyond.
} 
mology during and after the exile, and probably in dialogue with these, and with the development of apocalyptic thought especially in times of persecution, that the possibility of resurrection came to be acknowledged eventually (Luyten 1990:28-29; Wolff 1974: 165-166).

As was the case with reflection on the question of the meaning and value of suffering where no obvious guilt could be determined (Job, Psalm 73), so also the question of premature death of the faithful became a "theological" question, particularly since the exile. While other passages may hint in this direction, it is Isaiah 53 that clearly proclaims that the death of the innocent can be meaningful, even vicarious (Luyten 1990:23-25). And "only at the edges of the Old Testament... is the prospect of resurrection to new life mentioned" (Brueggemann 2002:48). However, these notions set the key for the New Testament Gospel message. There the death and resurrection of Jesus tear open the curtains to life beyond the grave, offering perspectives never thought of in the first Testament (Wolff 1974:176). But the essence of the Old Testament proclamation on life is held in esteem in all its glory: This earthly life is important and should be lived to its full in all its dimensions. Above all: the God who first revealed himself as Yahweh and became a physical human born in this world, in this life, as Jesus of Nazareth, He is the creator, source and giver of life in all its dimensions. It is Him who said: "I am the resurrection and Life; whoever believes in me shall live, even though (s)he dies" (John 11:25).

When we as modern day readers read the first Testament, New Testament perspectives may easily obscure our eyes from seeing what Old Testament faith community, be it as historians or prophets, as theologians or seemingly ordinary people in distress, said about life and death. But the vision of Christians from the "first world" is further clouded by 20 centuries of thought, from Greek to modern philosophy, and perhaps even more so by Western economic ideology of prosperity, inhibiting them to recognize the dimensions of life exhibited in the Old Testament and to face death in a meaningful way.

A major part of Bible readers today, however, read these Biblical texts from a totally different frame of reference. One of these "new" reading communities is African Christians, who read the Bible with a distinctive African world-view (see footnote 1). As will appear from the following synopsis, many aspects of the African view on life and death stand astonishingly close to that of the Old Testament. But there are likewise aspects which resemble Canaanite views, which the Old Testament faith explicitly rejects.

For Africans the focus is on this present earthly life (Wachege 2002:224-229). Meaningful life is communal and is viewed a holistic way (Frank 1999:29). Natural death at an advanced age is viewed positively over against untimely youthful death, which always creates a crisis. The creator god is viewed as the ultimate source of life. Belief in ancestors does not only create a link with the creator god, they also provide a means to cope with the phenomenon of death. A person (male or female) who dies a normal death has the hope of becoming an ancestor (Frank 1999:159-163). If the person has achieved some stature in the community and have descendents who would (like to) remember him or her, she will live on as part of this earthly community, though physically departed. He or she will continue to influence daily life even in a more profound and powerful way than while alive.

Unnatural death shows that the balance of life, of power (re. shalom) was upset (Frank 1999:118-130). What makes untimely or youthful death evil is the fact that the person has not had the opportunity to become "somebody" in the community, and worse, may not have 
off-springs to remember him or her ${ }^{17}$. This poses the danger of not becoming an ancestor and one may thus enter into forgetfulness (Frank 1999:185).

According to African world view death does not simply happen, it is caused by an external force (Jali 2000:13-19). Though ancestors are seldom believed to cause death, conditions caused by them which indicate their dissatisfaction, may eventually lead to death. Anger of ancestors can be appeased through the correct ritual means. Sometimes evil powers are believed to cause death. But usually these powers do not operate of their own accord. Human agents are believed to manipulate these powers through magical means. Evil individuals (commonly called witches) may thus cause death. In many cases, however, it is an ordinary member of the community who is suspected of using spells or substances (muti) to employ life destructing powers. To ward off these powers one has to make sure that you use even stronger muti. In exceptional cases, for example where a person lived a reckless life, he may be regarded as personally responsible for his own death. This is not always regarded as guilt, which would mean that an external agent like God has punished him. Disasters, particularly national disasters, may be regarded by some as direct punishment by God. In some cases death is accepted in a mere fatalistic manner.

It is not suggested here that this is how African Christians think about life and death. In fact a very wide spectrum of views exist among these believers. While some have been heavily influenced by Christian, and even western philosophical views, many others stand much closer to traditional views. Despite a vigorous onslaught on the belief in ancestors from missionary preaching, ancestors remain an integral part of most African Christians' thought about death and life after death. Diverse practices concerning the dead ${ }^{18}$ are devices to help the living cope with their loss. Also the extended period of conducting wakes and extravagant funeral procedures to give the diseased a "decent funeral", are essentially for the emotional benefit of the bereaved. It is particularly in this regard that Christian Churches today play a very important role in African communities at large.

Through contact with the Western world much of traditional Africa's harmonious communial life has disappeared through social factors like urbanization, ethnic wars, apartheid, education, economic pressures. In many communities, particularly urban communities, Christian churches have been providing alternative communial structures where otherwise displaced and marginalized people can experience a sense of belonging. They offer the opportunity to become part of a group and experience meaningful relationships and fellowship. They mostly meet in small fellowships, offering social and spiritual support to one another. In the lively worship services of African Independent Churches in particular members experience the closeness of God in fellowship with one another. Here they share their problems and pray out loud to God, or have the community to pray for them. In this fellowship they experience the fullness of life amidst the most pressing problems. African Independent Churches also usually operate much closer traditional African world view than is the case in mainline African Churches. They have devised contextual rituals and practices, some of which have lately been taken on also by some mainline churches, particularly cleansing, which assist believers in the process of bereavement.

17 Though there is a widespread belief in re-incarnation of a diseased in a new born baby, it is not a central perception about death with many peoples (Jali 2000:54-55). The dying person does not find consolation in the fact that he or she may "return" to this life through re-incarnation.

18 For example participation in traditional ceremonies by Christians, and newly devised Christian practices modelled on traditional ones, like ukubuyisa, unveiling of tombstones and remembrance of death date (Zulu 1998:35-45). 
Church communities in African society have always been deeply involved with bereaved families and in conducting funerals, not only of their own members, but most often also of those who did not associate with the Church. In the present age of Aids, a major part of the ministry of churches tend to deal with support to bereaved families and conducting funerals. While it is true that there is little time left for care for the bereaved after the funeral, simply because the next case(s) need urgent attention, this aspect of ministry has anyway seldom been properly attended to. Even a less developed aspect of ministry is the care for the dying (Frank 1999:1-3). This aspect of ministry has become crucial, not only because so many people are experiencing relatively long periods of intense physical suffering, but because those dying with Aids also wrestle with emotional issues as well as questions of faith.

Faith communities have an unique role to play in combating the spread of the HI-virus and to assist people living with Aids. In this the communication of the Biblical message on life and death should play a key role. The New Testament's unique view on death and life after death has to inform both Old Testament and African views in this regard. The Old Testament view of life, which in many regards has affinity with that of Africa, is particularly relevant in a situation where many people in the prime of life are facing inescapable death. The danger exists that the New Testament view of death (here-after) and (seemingly over-) emphasis on spiritual life may silence the holistic view of life in the Old Testament. Where this happens, the real needs of suffering people are effectively sidestepped.

In the Psalms the church has a powerful instrument in caring for persons confronted by untimely death because of Aids. Such persons are often troubled by feelings of guilt or anger towards life and towards God. They need to be helped to come to peace with themselves, with life and with death, and thus with their Creator. Simply reading a Psalm like Psalm 39 with such persons in a prayerful manner has the power to change lives, because they manage to express the emotions, the anger, fear and hope of a heart in distress.

In conclusion: For the Christian Church, the message of the New Testament remains central and normative when speaking about life and death. It challenges all current worldviews, African and Western alike, just as Israel's particular notion of Yahweh as the God of life challenged the world-views of its day. But, just as Israel's faith was in constant dialogue with its Umwelt, so the Biblical perspectives on life and death must remain in dialogue with modern views. For African believers, the two central Old Testament coping mechanisms helping persons to make peace with immanent death, namely to be part of a community, a community of faith, and prayer, like praying the Psalms, expressing ones deepest emotions, are particularly meaningful. In both these Western believers have much to benefit from both these traditions.

\section{BIBLIOGRAPHY}

Albertz, R 1979: צעק Schreien. In THAT II, E Jenni \& C Westermann (eds.) pp. 568-575. München; Chr. Kaiser Verlag.

Brueggemann, W 1986: Praying the Psalms. Winona; Saint Mary's Press.

Brueggemann, W 2002: Reverberations of Faith - A Theological Handbook of Old Testament Themes. London; John Knox Press.

Eichrodt, W 1982. Theology of the Old Testament. Vol. 2. London; SCM Press Ltd. 
Frank, ME 1999. African Notions of Sickness and Death in Pastoral Care to the Dying. (D.Th dissertation) Stellenbosch, US .

Hallote, RS 2001. Death, Burial, and Afterlife in the Biblical World-How the Israelites and their Neighbours Treated the Dead. Chicago, Ivan R Dee.

Jali, NM 2000. The African perception of Death, with special Reference to the Zulu: a Critical Analysis. (M.Phil dissertation) Stellenbosch, US.

Kraus, H-J 1978: Psalmen. BKAT. Neukirchen-Vluyn; Neukirchener Verlag.

Kraus, H-J 1979: Theologie der Psalmen. Neukirchen-Vluyn; Neukirchener Verlag.

Luyten, J 1990: Perspectives on Human Suffering in the Old Testament. In God and Human Suffering, J Lambrecht \& RF Collins (eds.). Chicago; Peeters Press.

Martin-Achard, R 1978: גור Als Fremdling weilen. In THAT I, E Jenni \& C Westermann (eds.) pp. 409-412. München; Chr. Kaiser Verlag.

Schult, H 1979: שמע Hören. In THAT II, E Jenni \& C Westermann (eds.) pp. 974-982. München; Chr. Kaiser Verlag.

Schwertner, S 1978: אין Nichtsein. In THAT I, E Jenni \& C Westermann (eds.) pp. 127-130. München; Chr. Kaiser Verlag.

Von Rad, G 1975: Old Testament Theology. Vol. I. London; SCM Press Ltd.

Wachege. NP 2002. Living to Die, Dying to Live. African Christian Insights. Nairobi, Signal Press Ltd.

Weiser, A 1971: The Psalms. OTL. London; SCM Press Ltd.

Westermann, C 1979: קוה Hoffen. In THAT II, E. Jenni \& C. Westermann (eds.) pp. 619-629. München; Chr. Kaiser Verlag.

Wolff, HW 1974: Antropologie des Alten Testaments. München; Chr. Kaiser Verlag.

Zulu, E 1998: An Ngoni Assessment of the role of Ancestors within Ancient Israelite World View and Religion in Genesis 11:28-50:26. (DTh dissertation) Stellenbosch, SU. 